\title{
VAL I MAY ySGRIfENEDIG: Derivatives With SuffiX - EDIG IN Three Early Modern Welsh Texts
}

\author{
Elena Parina \& Lara Geinitz
}

\section{Introduction}

The association of Latin and English past participles with Welsh derivatives with the suffix -edig has a long tradition. ${ }^{1}$ In the $16^{\text {th }}$ century, Gruffydd Robert makes subtle points about the partial correspondence of edig-derivatives with Latin participles (see Robert 1939: 172-6, discussed in detail in Poppe (in prep.)). Referring to English, William Gambold $(1727,1833: 87)$ states that "[t]he participles of the Preter sense, which in English end in $d$, $t$, or $n$, are made in Welsh by adding edig to the radix of each verb's formation, as câr, caredig; dysg, dysgedig; lladd, lladdedig". In his outline of Welsh verbal morphology, John Strachan suggests that "[t]here is a passive participle in -edic and a verbal [sic] of necessity in -adwy" (Strachan 1909: 63).

Following him, John Morris-Jones discusses edig-derivatives as part of the regular verbal paradigm, and he too describes their meaning in terms of Latin grammar: "Verbal adjectives are formed from the stem of the verb either without a suffix or with the suffixes -edig,-adwy ... all regular transitive verbs may have v.a.'s in -edig and -adwy. The former has usually the sense of a past pass. participle, the latter of a fut. pass. part., or gerundive" (Morris-Jones 1913: 396). In a recent publication on translations between English and Welsh, Rottet and Morris (2018: 312) note that $e$ dig-derivatives are "mainly associated with the English past participle", as in the example 'her voice was educated' $\approx$ 'roedd ei llais yn swnio'n addysgedig'. But they also show that this equivalence is only partial and that edig-derivatives "can sometimes be better rendered in English as present participle equivalent" (as in ' $i$ anadlu'r ager a godai o'r jwg o ddw wr berwedig' $\approx$ 'to inhale the steam from a jug of boiling water'); furthermore, while translating from English, "it should be not taken for granted that a verb-noun modified by the adjectival suffix - edig ${ }^{2}$ can always be an acceptable equivalent for an English past participle" (as in "Taking it

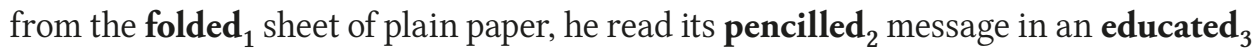

1. Research for this paper was conducted within the project 'The Welsh Contribution to the Early Modern Cultures of Translation: Sixteenth-Century Strategies of Translating into Welsh', located at the University of Marburg and led by Dr Elena Parina and Prof. Erich Poppe, which is a part of the German Research Council's (DFG) Priority Programme 2130 'Cultures of Translation in the Early Modern Period'.

2. For a more adequate description of derivation with this suffix, see Russell (1990: 76-80, 103-8) and Zimmer (2000: 488-96). 
and quite shaky $_{4}$ italic...' $\approx$ 'Cymerodd y darn papur gwyn a oedd wedi ei blygu

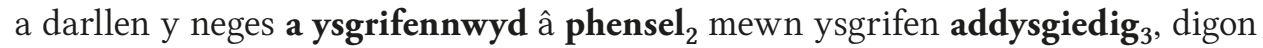
crynedig $_{4},{ }^{3}$ (Rottet \& Morris 2018: $\left.312-3\right)$ ).

In the analysis of the texts of Oxford, Jesus College MS. 119 (The Book of the Anchorite of Llanddewi Brefi, dated 1346, hereafter referred to as Llyfr yr Ancr or $L l A),{ }^{4}$ Parina and Poppe found that for the translated texts we can compare with an assumed Latin source about two thirds of edig-derivatives correspond to Latin past passive participles (see Parina \& Poppe (forthcoming)). We demonstrated that most of the lexemes used are derived from verbal stems and that other derivational patterns exist, but are exceptions. We were also able to establish different strategies of their usage by different translators; in some texts, the suffix seemed to be more productive than in the others.

As our research moved on towards the $16^{\text {th }}$ century, we were interested in trends in the usage of edig-derivatives in this later period in the history of the Welsh language. The aim of this contribution is to analyse a sample of three translated texts from the $16^{\text {th }}$ century: Gesta Romanorum, Treigl y Marchog Crwydrad and Perl mewn Adfyd. All of them are translated from English, and our focus is similar to that in the study of the texts in Llyfr yr Ancr: for each text, we aim to identify the main types of grammatical equivalents in the source language. Our main question is the degree of correspondence with English past participles, but we will also look at the derivational patterns and the productivity of the suffix. In this way, we hope to detect diachronic trends in the development of the edig-suffix.

\section{Information on the texts analysed}

All three texts are translated from English, but English is not the language of their ultimate source text: the original of Gesta Romanorum was composed in Latin; Treigl y Marchog Crwydrad in French; and Perl mewn Adfyd in German.

The Latin Gesta Romanorum must have been composed in the $14^{\text {th }}$ century; their manifold manuscript witnesses were studied by Oesterley (1872), who established a separate Anglo-Latin version of the texts. This version is found both in Latin (in manuscripts) and in English (in three manuscripts and in print). The first edition was published by Wynkyn de Worde in 1510 and was reprinted many times; in 1577, Richard Robinson printed a revised Protestant version (Williams 2000: xviii-xix). The Welsh text is found only in one manuscript, Aberystwyth, National Library of Wales MS. 13076 B (Llanover B 18), dated s.xvi/xvii, written by Llywelyn Siôn (on the

3. In this example, an English past participle corresponds to an adjective with the suffix -edig only once (educated - addysgiedig). In the pairs indexed with 1 and 2, the English past participle corresponds to Welsh relative clauses, and in the pair indexed with 4, the English verbal adjective is translated by an edig-derivative.

4. First edited in Morris-Jones and Rhŷs (1894), quoted in this article after Luft et al. (2013). 
scribe, see Philipps 1959). The correspondences between English and Welsh texts are so close that there is no doubt that the Welsh text was translated from English, but

[a] comparison between the moralizations of the Welsh Gesta and those of Wynkyn de Worde and the protestanised version of Richard Robinson respectively shows that the Welsh version is not a hand-tied translation but a free rendering. Out of 205 points of comparison, the Welsh Gesta was 45\% independent of both English texts; there was a $31 \%$ agreement with Wynkyn de Worde, a 19\% agreement with Robinson but only a $4 \%$ total agreement with both.

(Williams, in preparation)

For this study, we analysed a sample of 10,000 words (starting with the beginning of the fifth story) taken from the edition by Williams (2000), comparing the passages to both English print editions (1510 and 1577). ${ }^{5}$ We refer in the following to this text as Gesta Romanorum or GR.

The French work Le Voyage du Chevalier Errant was published by Jean Cartigny (c.1520-c.1578-80) in Antwerp in 1557 (Smith 2002: xii). It was translated into several languages; the English translation by William Goodyear was published in London in 1581, under the title The Voyage of the Wandering Knight, and was dedicated "to the right worshipfull sir frauncis drake, knight”. In Welsh, Treigl y Marchog Crwydrad appears in five manuscripts, the earliest of which is Aberystwyth, National Library of Wales, Llanstephan MS. 178, dated c.1585 - only five years after the English translation was published (Smith 2002: xii). The translation refers to the English version as the source (see Smith 2000: 3). For this study, we analysed the first 10,000 words of the Smith 2002 edition. In the following, we refer to this text by its traditional Welsh title Marchog Crwydrad or MC (references are given to lines).

Both Gesta Romanorum and Marchog Crwydrad belong to the Glamorgan school of translation, a Recusant milieu responsible both for copying earlier texts as well as for translating religious and moralistic texts popular in England and on the Continent in the $15^{\text {th }}$ and $16^{\text {th }}$ centuries (Thomas 1997: 255). It is important that their language is supposed to be unaffected by that of the most influential translator into Welsh of the time, William Salesbury, and of further Bible translators (see Williams 1948: 176), which gives us an opportunity to look at two strands of the Welsh prose language.

Our last text belongs to a different layer of Welsh literature - the Protestant one, which explicitly pays tribute to the Bible translators. A German treatise

5. The data from Gesta Romanorum and Marchog Crwydrad are based mainly on the BA thesis by Lara Geinitz (2019). 
Ein Kleinot Von Trost und Hilf in allerley Trübsalen was published by Otto Werdmüller in Zürich in 1548. In 1574, an English translation by Miles Coverdale was published under the title A Spirituall, and most Precious Pearle... in London. ${ }^{6}$ In 1595, Hugh Lewis (on the translator, see Williams 1959) published his translation of the English version in Oxford (the first Welsh book printed in Oxford), referring to the 1588 translation of Bible with the highest esteem. For this study, we used the parallel edition of the Welsh and English texts established in Parina (2015), which includes 15,000 Welsh words (from the first 13 chapters), taken from the Mittendorf and Willis (2004) Historical Corpus of the Welsh Language 1500-1850 with the permission of David Willis. We refer in the following to this text as Perl mewn Adfyd or PmA.

\section{English equivalents in the assumed sources}

First, we will look at the English equivalents in the source texts and try to distinguish the main trends. The data is summarised in the following table:

Table 1. Grammatical classes of the English equivalents in the $16^{\text {th }}$-century texts

$\begin{array}{lcccccccc}\begin{array}{l}\text { English } \\ \text { equivalents }\end{array} & \text { GR } & \begin{array}{c}\text { \% in } \\ \text { GR }\end{array} & \text { MC } & \begin{array}{c}\text { \% in } \\ \text { MC }\end{array} & \text { PmA } & \begin{array}{c}\text { \% in } \\ \text { PmA }\end{array} & \text { Total } & \begin{array}{c}\text { \% } \\ \text { total }\end{array} \\ \begin{array}{l}\text { Past } \\ \text { participle }\end{array} & 13 & 39.4 & 6 & 22.2 & 14 & 31.1 & 33 & 31.4 \\ \begin{array}{l}\text { Adjective } \\ \text { Noun }\end{array} & 0 & 0 & 11 & 40.7 & 24 & 53.3 & 35 & 33.3 \\ \begin{array}{l}\text { Adverb } \\ \text { Present }\end{array} & 2 & 6,1 & 3 & 11.1 & 4 & 8.9 & 9 & 8.6 \\ \text { participle } & 0 & 0 & 2 & 7.4 & 0 & 0 & 2 & 1.9 \\ \text { Other case } & 3 & 6.7 & 2 & 7.4 & 2 & 4.4 & 7 & 6.7 \\ \text { Total } & \mathbf{3 3} & \mathbf{1 0 0} & \mathbf{2 7} & \mathbf{1 0 0} & \mathbf{4 5} & \mathbf{1 0 0} & \mathbf{1 0 5} & \mathbf{1 0 0}\end{array}$

\subsection{Past participles}

As can be seen from the table, English past participles are translated with edig-derivatives in every text:

6. We quote the English text from the 1812 edition in modernised orthography. 
(1)

Than sayd he I am boū|de euery daye too paye .ii. d. to my fader for whan I was yonge my fader spente on me .ii. d. dayly

$(G R-\mathrm{WdW} 1510)^{7}$

A'r gof a ddywad, 'Idd wyf j yn rwymedig ${ }^{8}$ i daly dwy baenydd y'm tad, kans pan oeddwn j yn jevank, ef a gostawdd y'm tad ddwy baenydd vy magv.

(GR-Williams 2000: 553)

(2)

But it is forbidden to take counsell of fooles (Voyage 1581: 5)

ond i mae yn warddedig ${ }^{9}$ gymeryd cyngor gan ffolaid (MC-Smith 2002: 165)

(3)

Be it in case that thou wert deprived of all manner of bodily comfort; yet in thy breast and heart thou hast the knowledge of Jesus Christ

(Pearle 1579/1812)

Bwrw dy fod 'n ymddifad, ne 'n ysbailedig, ${ }^{10}$ o bob diddanwch corfforawl, etto yn dy ddwyfron a 'th galon, mae genyt wybodaeth o Iesu Christ

(Perl 1595)

We find English past participles translated by edig-derivatives in different syntactic functions; in English, they can be used attributively (4), predicatively (5) or in passive constructions $(1-3,6-7)$ :

7. The conventions for the examples are as follows: we quote first the source text, then the Welsh translation. For Gesta Romanorum, we quote the English text from the EEBO encoded text of the 1510 edition as WdW 1510, without page numbers, since in the edition the pages are unnumbered. We quote the Welsh text following Williams (2000), giving reference to the line where the word discussed is found. For the $M C$ text, we quote the English text using the EEBO encoded text as Voyage 1581 and reference to the page, and the Welsh text following Smith (2002), giving reference to the line where the discussed word is found. For Perl mewn Adfyd, we use the parallel edition (Parina 2015), referring to the texts as Pearle $1579 / 1812$ and Perl 1595.

8. GPC s.v. rhwymedig, from the stem of the verb rhwymaf' to bind'; $1^{\text {st }}$ att. $13^{\text {th }} \mathrm{c}$.

9. GPC s.v. gwaharddedig, from the stem of the verb gwaharddaf'to prohibit'; $1^{\text {st }}$ att. 1346.

10. GPC s.v. ysbeiliedig, from the stem of the verb ysbeiliaf'to plunder'; $1^{\text {st }}$ att. $13^{\text {th }} \mathrm{c}$. 
(4) and he comforted them also with the promise of the blessed seed (Pearle 1579/1812) ac ef a 'i diddanodd hefyd a gaddewid o'r bendigedic ${ }^{11}$ had (Perl 1595)

(5) If the generation of mankind had been conformable unto the law of God, and had not swerved from the same, it had been altogether thoroughly happy and blessed evermore

(Pearle 1579/1812)

pe i buase hiliogaeth dyn, yn vfuddol i gyfreithie duw, ac heb yscogi oddiarnynt, e fuasse yn ollawl yn gwbl ddedwydd, fendigedig, yn dragowydd

(Perl 1595)

(6)

And to theym than sayd the ymage lyfte vp your eyen and beholde what is wryten in my forhede

(GR-WdW 1510)

A'r ddelw a ddywad wrth y kenadav, 'Edrychwch beth a sydd yn ysgryvenedig ${ }^{12}$ y'm talken.'

(GR-Williams 2000: 521)

(7)

as it is written (Voyage 1581: 14)

val i may ysgrifenedig (MC-Smith 2002: 437)

\subsection{Adjectives and adverbs}

When we assess the data from all the texts together, the English equivalent most frequently translated by an edig-derivative is not a past participle, but an adjective. Interestingly, the texts here vary considerably. While in Gesta Romanorum no such examples are found, in Marchog Crwydrad and Perl mewn Adfyd this type of equivalence occurs more often than that discussed in 3.1. Some of these equivalents recall the trends identified in $L l A$. Thus, in $M C$, we find examples of English adjectives (and adverbs, see ex. 15) with the suffix -able, which corresponds to (and partly originates from) the Latin suffix -(b)ilis. ${ }^{13}$

11. GPC s.v. bendigedig, from the stem of the verb bendigaf'to bless'; $1^{\text {st }}$ att. $12^{\text {th }} \mathrm{c}$.

12. GPC s.v. ysgrifenedig, from the stem of the verb ysgrifennaf 'to write'; $1^{\text {st }}$ att. $13^{\text {th }} \mathrm{c}$.

13. See OED s.v. -able, suffix. 
(8)

Euerie one ought to for|sake her, for $\mathrm{y}^{\mathrm{t}}$ the end of such as be ruled by her preceptes, tread in her paths, \& daūse after her pipe, is proued by expe|rience to be daungerous, deadly, and dampnable. ${ }^{14}$

(Voyage 1581: 28)

Canys pob dyn a ddylyei chysay hi ag ymwrthod a hi, canys diwedd pob dyn ag a sydd yn cymeryd y rhioli gan Ffolineb, ag yn cerdded y llwybrey hi, ag yn dawnsio gyda'y ffibe hi, periglys marwol a damnedig ${ }^{15}$ ydiw.

(MC-Smith 2002: 898)

Compare the following example from Ystoria Lucidar:

(9)

Ar lleuat a|syr a|wisgir yn andywededic echdywennedigrwyd.

(LlA, Ystoria Lucidar 59v)

Luna et stellae vestientur ineffabili splendore.

(Lefévre 1954: 463)

Moon and sun will be dressed in ineffable splendour.

with annywededig (negation + dywed- 'to speak' + -edig) translating ineffabilis (see also Rowles 2008: 155, 314)

There are also examples of edig-derivatives translating adjectives that cannot be interpreted as passive ${ }^{16}$ (broadly speaking passive):

(10)

And though I am narrow \& painfull to passe, yet if thou wilt follow me, I wil make thée merry, \& guid thée in $y^{\mathrm{e}}$ very way, which God hath ordeined to lead vnto true blessednes.

(Voyage 1581: 31)

14. Compare also 'that mans death is damnable' (Voyage 1581: 33) $\approx$ 'may bywyd y rhaini a'y hangay yn ddamnedig' (MC-Smith 2002: 1068)

15. GPC s.v. damnedig, from the stem of the verb damnaf'to condemn'; $1^{\text {st }}$ att. 1552 - see Smith (2002: xxxi) on further English loanwords in the text.

16. For a more precise terminology - patient-oriented for passive and agent-oriented for passive participles/adjectives - see Haspelmath 1994: 152-4. 
Ag er fy mod i yn gyfing ag yn boenedig ${ }^{17}$ y'm tramwy, eto, os myny vy nilyn i, mi a'th wnaf yn llawen, ag a'th arwenaf yn gyfarwydd y'r ffordd iniawn, yr hon a ordeinoedd Duw i vyned i wir ddedwyddyd.

(MC-Smith 2002: 995)

An example have we set before our eyes in the prodigal and desperate son, which did so humble and submit himself

(Pearle 1579/1812)

mae i ni siampl o hyn, o flaen ein llygaid, o ' $\mathrm{r}$ mab treilgar, anobeithedic, ${ }^{18} \mathrm{yr}$ hwn, a 'i vfuddhaodd, ac a'i darostyngodd i hunan

(Perl 1595)

And with such manner of persons the whole trade of their former life, with all their labour, travail, and afflictions, in their superstitious serving of God.

(Pearle 1579/1812)

Ac i "rr cyfryw ddynion, oll gwrs i bywyd o 'r blaen, i oll lafur, a "i trafael, a 'i goglud oll, yn ei argoeledig ${ }^{19}$ wasnaethu duw.

(Perl 1595)

As well as poenedig above, trancedig, another active adjective, is used already early and found in LlA in the same sense (yr byt tranghedic (14v) 'of the transitory world' for transitorium mundum (Lefévre 1954: 378)):

(13)

How transitory and vain are all things that we have here upon earth!

(Pearle 1579/1812)

O mor drancedig ${ }^{20}$ ac mor ofer yw ' $r$ oll bethau sydd genym ar y ddayar yma?

(Perl 1595)

17. GPC s.v. poenedig, from the stem of the verb poenaf to hurt'; $1^{\text {st }}$ att. $13^{\text {th }} \mathrm{c}$.

18. GPC s.v. anobeithiedig, from the stem of the verb anobeithiaf 'to despair'; $1^{\text {st }}$ att. 1595.

19. GPC s.v. argoeledig, from the noun argoel 'sign, omen'; $1^{\text {st }}$ att. 1595.

20. GPC s.v. trancedig, from the stem of the verb trengaf'to die, perish'; $1^{\text {st }}$ att. $13^{\text {th }} \mathrm{c}$. 
Similarly, adverbs are translated sometimes by edig-derivatives. Such examples are found in all the three texts:

And whan the Emperours solne sawe that he came vnto hym and salued hym reuerently and sayd. My lorde lo I gyue to $\mathrm{y}^{\mathrm{e}}$ this balle of golde on my faders behalfe.

$(G R-\mathrm{WdW} 1510)$

Pan welas mab yr amherawdr hynny, ef a ddaüth geir bronn y brenin newydd, ag a'i nrydeddawdd ef yn ostyngedig, ${ }^{21}$ gan ddwedvd, 'Arglwydd, dyma bel o aür, yr honn a wyf $\mathrm{j}$ yn ẏ roddi y ti wrth wllys vy nhad.'

(GR-Williams 2000: 64-5)

Saint Luke very notably and sincerely hath deliuered in writing, the painfull and holy perigrination of that great vessell of election Saint Paule, together with the great trauell hée tooke to preach the Gospell, and the faith of Iesus Christ, to all the Gentiles.

(Voyage 1581: 1)

A hefyd Saint Lvwc yn nodedig ${ }^{22}$ ag yn byraidd a draethoedd o boen y bendigaid berindod a wnaeth y mawr lestr dewisedig ${ }^{23}$ Sant Pawl a'r gofid hefyd a gymerth ef i bregethy'r Efengil a ffydd Iesu Grist y'r cenedloedd oll.

(MC-Smith 2002: 26)

Trouble and affliction do help and further us to the knowledge of ourselves, and of God also, and especially to wisdom.

(Pearle 1579/1812)

Gorthrymder ac adfyd, a 'n helpiant, ac a 'n cynorthwyant, i 'n adnabod ein hunain, a duw hefyd, ac yn anwedic ${ }^{24}$ a ddyscant ddoethineb.

(Perl 1595)

21. GPC s.v. gostyngedig, from the stem of the verb gostyngaf to lower, bow'; $1^{\text {st }}$ att. late $15^{\text {th }} \mathrm{c}$.

22. GPC s.v. nodedig, from the stem of the verb nodaf'to note'; $1^{\text {st }}$ att. $14-15^{\text {th }} \mathrm{c}$.

23. The equivalents vessel of election: llestr etholedig go back to Acts 9:15, where a noun phrase with the second noun being used as a genitive of the characteristic attribute, a construction typical for

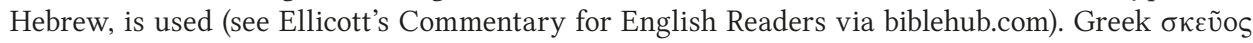
$\dot{\varepsilon} \kappa \lambda$ ơñ is translated in the Vulgate as vas electionis, but as chosen vessel in the King James Bible and llestr etholedic in both Welsh translations (1567 and 1588).

24. GPC s.v. enwedig, from the stem of the verb enwaf 'to name'; $1^{\text {st }}$ att. $14^{\text {th }} \mathrm{c}$. 


\subsection{Further equivalents}

Not numerous in our sample, but still interesting, are the cases where edig-derivatives translate English equivalents other than past participles and adjectives (and adverbs).

In $M C$, twice an edig-derivative translates an English present participle (compare the examples from Rottet and Morris quoted in the introduction):

First he fashioned their standing Images, \& set thē in ye midst of ye citie of Babilon, \& that was ye first begin|ning of Idolatry

(Voyage 1581: 14)

Yn gyntaf, vo lynioedd y delway safedig ${ }^{25}$ hwynt, ag a'y gosodes ynghenol dinas Pabilon, ahyny oedd y dechreyad cyntaf ar y gay addoliaeth.

(MC-Smith 2002: 423)

This type was analysed by Russell (1990: 78), who showed that "active verbal adjectives" are formed from intransitive verbs. We saw a similar example with an additional potential meaning in trancedig 'transitory' above. In Llyfr yr Ancr, a corresponding example is:

Sicut dulcis fons sitientem agricolam (Lefévre 1954: 470)

megys ffynnan o|dfuyr melys yn dadebru llauur6yr sychedic (Ystoria Lucidar, 64v)

We also see nouns being translated by edig-derivatives; two examples will be discussed here. The nominalised plural form caredigion occurs in our sample of Gesta Romanorum 13 times as the address in the moralisatio or interpretation, as in:

Dere frendes this Emperour is the fader of heuen (GR-WdW 1510)

Vy ngharedigion, ${ }^{26}$ yr amherawdr hynn yw'r Tad o'r nef (GR-Williams 2000: 85)

The address fy ngharedigion 'my beloved' with the possessive pronoun is not fully equivalent to the English dere frendes in the corresponding passages in both the

25. GPC s.v. safedig, from the stem of the verb safaf'to stand'; $1^{\text {st }}$ att. $13^{\text {th }} \mathrm{c}$.

26. GPC s.v. caredig, from the stem of the verb caraf 'to love'; $1^{\text {st }}$ att. $13^{\text {th }} \mathrm{c}$. Instances of using this word as an address are found already in the $13^{\text {th }}$ century: cf. fo ditheu uyg caredic $i$ (Brut Dingestow, NLW 5266: 262, after Isaac et al. 2013 corpus Rhyddiaith $13 \mathrm{~g}$. 'flee, my beloved one' - translating Latin fuge, dilecte mi (Geoffrey of Monmouth X 165: 225)). 
Wynkyn de Worde 1510 and Robinson 1577 versions, nor to the Latin carissimi in the ultimate source (see Oesterley 1872: 274, 276, 277). But the third story of the collection (not attested in our Welsh manuscript, which starts in the middle of the fourth story; see above) the address in the interpretation is $M y$ friends (in both versions, GR-WdW 1510: 6, GR-Robinson 1577/1595: 9)

Another interesting example is found at the very beginning of Marchog Crwydrad. Whereas the introductory sentence starts in English with a learned word, historiographer, in Welsh, the translator paraphrases the sentence and makes gwur dyskedigion 'learned men' the subject of it and ystoriae diwiol a budol 'divine and worldly stories' the direct object:

MANY HISTORIOGRAPHERS both Poets and Orators, as well prophane as diuine, haue by writing notified diuers persons, with their voyages \& aduentures.

(Voyage 1581: 1)

Llawer o ystoriae diwiol a budol a draethes gwur dyskedigion ${ }^{27}$ y ddangos treigl ag antyrey llawer o ddynon yn y byd yma.

(MC-Smith 2002: 7)

Many divine and worldly stories were told by learned men to show voyages and adventures of many persons in this world.

(translation of the Welsh text by E. Parina)

This section discussed several grammatical classes of English words that are translated by edig-derivatives in the sample. Past participles are present in every text. Another important category, adjectives, is found frequently in the two later texts - even, in the Perl mewn Adfyd sample, in more than half of the cases - but is absent in our Gesta Romanorum sample. Present participles are found only twice (one lexeme) in one text, which shows that this equivalence is rare in our sample. We have also seen nouns translated by edig-derivatives, but these examples are more indicative of individual translators' strategies than of any grammatical trends.

27. GPC s.v. dysgedig, from the stem of the verb dysgaf'to teach'; $1^{\text {st }}$ att. $14^{\text {th }} \mathrm{c}$. Cf. also similar equivalence E. clerke $\approx$ W. gwr dysgedig in Gesta Romanorum: This Emperoure called vnto hym a clerke: A'r amherawdr a alwodd ar wr dysgedig a oedd yno (GR-Williams 2000: 503-4). Also noteworthy is the agreement of the adjective - this being the only case out of 15 in our sample from three $16^{\text {th }}$-century texts where the edig-attribute is used in plural form with a plural head (on the plurals of adjectives in -edig in Middle Welsh see Nurmio 2019: 198-203). 


\section{Comparison with translations from Latin in Llyfr yr Ancr}

The following table shows the relative frequency of certain grammatical classes translated with edig-derivatives from Latin in the texts of Llyfr yr Ancr, where we have access to the assumed sources, and separately in Ystoria Lucidar, with some data for the $16^{\text {th }}$-century sample from Table 1 repeated here for readers' convenience.

Table 2. Grammatical classes of the Latin and English equivalents in the $14^{\text {th }}$ - and $16^{\text {th }}$-century texts

\begin{tabular}{|c|c|c|c|c|c|}
\hline & $\begin{array}{c}\text { All texts } L l A \\
\text { with assumed } \\
\text { source }\end{array}$ & Lucidar & GR & MC & $\operatorname{PmA}$ \\
\hline $\begin{array}{l}\text { past } \\
\text { participle }\end{array}$ & 117 & 87 & 13 & 6 & 14 \\
\hline pp in $\%$ & $67.6 \%$ & $70.2 \%$ & $39.4 \%$ & $37 \%$ & $31.1 \%$ \\
\hline adj & 33 & 25 & 0 & 11 & 24 \\
\hline adj in $\%$ & $19.1 \%$ & $20.2 \%$ & $0 \%$ & $40.7 \%$ & $53.3 \%$ \\
\hline Total & 173 & 124 & 33 & 27 & 45 \\
\hline
\end{tabular}

Comparing the two sets of data, we see that the correlation of edig-derivatives with past participles is stronger in the $L l A$ texts. In the $16^{\text {th }}$-century texts, edig-derivatives also translate past participles, but at least in our sample the proportion of this group of examples to the total number is less for every text. We also see the greater number of adjectives translated by edig-derivatives in our sample from the two later texts. On the level of particular lexemes and grammatical classes, the examples from the $16^{\text {th }}$-century sample show many resemblances to the language of Llyfr $y r A n c r$, but there is also a quantitative change. Further analyses of larger samples are necessary to test whether these trends can be substantiated.

\section{Derivational patterns and time of attestation}

It seems that we can detect diachronic change also in the derivational patterns of edig-derivatives, even if only tentatively, given the small size of our sample. 
Table 3. Derivational patterns of edig-adjectives in the $16^{\text {th }}$-century texts

$\begin{array}{ccccccc} & \text { GR } & \text { \% GR } & \text { MC } & \text { \%MC } & \text { PmA } & \text { \% PmA } \\ \text { Vs } & 12 & 100 & 15 & 83,3 & 20 & 87 \\ \text { Vn } & 0 & 0 & 1 & 5,6 & 1 & 4,4 \\ \text { N } & 0 & 0 & 1 & 5,6 & 2 & 8,7 \\ \text { A } & 0 & 0 & 1 & 5,6 & 0 & 0 \\ \text { Total } & 12 & 100 & 18 & 100 & 23 & 100\end{array}$

In $G R$, we find only derivations from verbal stems; in both $M C$ and $P m A$, other derivational patterns are also found. In $M C$, a lexeme is attested that is recorded in GPC only from 1722 onwards (in a manuscript of Gambold's dictionary):

(21)

all manner of warres both forreine and ciuill, attempted (Voyage 1581: 5)

a phob ryw ryfel yn vwriadedig ( $M C$-Smith 2002: 180)

The word bwriadedig 'attempted; proposed, intended, designed' is derived from the noun bwriad 'aim' according to GPC, but an alternative derivation from the verb stem of the corresponding verb bwriaduis also possible (likewise argoeledig < argoelaf and cancredig < cancraf). The same derivational pattern is found twice in PmA-in argoeledig above (this being the first attestation of the word), and in cancredig:

The rusty and cankered iron, through the file is made bright and smooth

(Pearle 1579/1812)

Yr hayarn rhydlyd, cancredic, gan y llif ddur, a loewir, ac a lyfnheir (Perl 1595)

Cancredig 'cancerous, gangrenous; rusty' is derived from cancr 'cancer' and is an adjective first found in this text. It also is most likely induced by its English equivalent. A comparison between the derivational patterns found in Llyfr yr Ancr and in the three $16^{\text {th }}$-century texts yields the following results: 
Table 4. Derivational patterns of edig-adjectives in the $14^{\text {th }}$ - and $16^{\text {th }}$-century texts ${ }^{28}$

$\begin{array}{lccccc} & \begin{array}{c}\boldsymbol{L} \boldsymbol{L A} \\ \text { total } \\ \text { types }\end{array} & \begin{array}{c}\text { Ystoria } \\ \text { Lucidar }\end{array} & \text { GR } & \text { MC } & \text { PmA } \\ \text { VS } & 70 & 36 & 12 & 15 & 20 \\ \text { VS in \% } & 93.3 \% & 92.3 \% & 100 & 83.3 \% & 87 \% \\ \begin{array}{l}\text { All other } \\ \text { patterns }\end{array} & 5 & 3 & 0 & 3 & 3 \\ \begin{array}{l}\text { All other pat- } \\ \text { terns in } \%\end{array} & 6.7 \% & 7.7 \% & 0 & 16.7 \% & 13 \% \\ \text { Total } & \mathbf{7 5} & \mathbf{3 9} & \mathbf{1 2} & \mathbf{1 8} & \mathbf{2 3}\end{array}$

We can thus see that derivation from verbal stem remains the default pattern, but the proportion of other patterns increases slightly in the sample of the two later texts. Certainly, these trends need to be checked on a larger sample.

Derivational patterns are connected to the question of the productivity of the suffix. An indication of its productivity in the ideolect of the translator could be the time of first attestation. While in Gesta Romanorum all the edig-lexemes are attested at least already in the $15^{\text {th }}$ century, in the sample of Marchog Crwydrad there are three lexemes recorded only from the $16^{\text {th }}$ century onwards, and in Perl mewn Adfyd there are six, with four of them, according to GPC (argoeledig, cancredig, pydredig, anobeithedig), being first attested in this text.

\section{Conclusion}

Our analysis of grammatical classes of English words translated by edig-derivatives in a sample of three $16^{\text {th }}$-century texts shows that the correspondence of edig-derivatives with past participles varies in them and is less obvious in the two later texts, Marchog Crwydrad and Perl mewn Adfyd, than in the Gesta Romanorum. When we compare the results to the $14^{\text {th }}$-century data from Llyfryr Ancr, we see that the link with the past participle in the source language weakens. On the other hand, more adjectives are being translated by edig-derivatives in our sample. This comparison

28. In this table lexemes like cancredig are counted according to the derivation suggested in GPC, although, as stated above, derivation from the corresponding verb stem is also viable-we would like to thank the anonymous reviewer for drawing our attention to this alternative. 
between the source text and the target text helps us to approach Welsh data from a contrastive linguistics perspective - seeing both the domains where the participles of Latin and English intersect with Welsh edig-derivatives and the cases in which Welsh edig-derivatives have different semantics.

Concerning derivational patterns, our small sample yields no examples of derivation from nouns in Gesta Romanorum, but possibly there are some isolated examples in the two later texts. We also observe that Marchog Crwydrad and Perl mewn Adfyd use more words that are not previously attested, and this might be an indication of the productivity of -edig as an adjectival suffix.

The sample analysed here thus appears to contradict Russell's observation that "in later Welsh -edig became a full-scale passive participle marker as the few active -edic derivatives were superseded by other patterns" (Russell 1990: 79). Whether the development of the suffix in Early Modern Welsh is indeed more complex than the trajectory suggested by Russell or whether our findings result from the smallness of the text sample remains to be studied. For future analysis, extending both the number of texts for the period explored in this pilot study as well as the chronological range of Welsh texts, including translations, will help to arrive at a clearer picture. This, in turn, could facilitate a comparison of Welsh data with that of other languages apart from English and Latin. ${ }^{29}$

\section{Philipps-Universität Marburg (Elena Parina \& Lara Geinitz) Institute of Linguistics, Russian Academy of Sciences, Moscow (Elena Parina)}

29. For a broad typological perspective on participles in the languages of the world, see Shagal (2019); on a study of Russian verbal adjectives, see Generalova (2016). 
GPC

GR-Robinson

$1577 / 1595$

$G R-$ WdW 1510

$G R-$ Williams (2000)

$M C-S m i t h(2002)$

Pearle 1579/1812

\section{Abbreviations}

GPC Online. University of Wales Centre for Advanced Welsh \& Celtic Studies, 2014. http://geiriadur.ac.uk/ gpc/gpc.html.

Robinson (1577/1595), A record of auncient histories, entituled in latin: Gesta romanorum discoursing vpon sundry examples for the aduancement of vertue, and the abandoning of vice. no lesse pleasant in reading, then profitable in practise (1595). London, By Thomas Est. ProQuest.

Gesta Romanorum (1510), London, Enprynted at London in Flete streete, by me Wynkyn de Worde. ProQuest.

Williams, P., 2000, Gesta Romanorum, Caerdydd: Gwasg Prifysgol Cymru.

Smith, D. M., 2002 Treigl y Marchog Crwydrad [The Voyage of the wandering knight], Caerdydd: Gwasg Prifysgol Cymru.

Werdmüller, O., 1511-52 (1579), A spiritua[l and] most precious [pearle tea]ching al men to lou[e \& em]brace the crosse as a most [sure \&.] necessary thing vnto the soul w[hose] comfort is to be taken [thereof] wher and how both consolation and aid in all maner of affliction is to bee sought, and againe hovv all men shoulde behaue themselues therein according to the word of god / written for thy comfort by a learned preacher otho VVermulierus; and translated into englishe by M. miles coverdale, London, Jmprinted at London by Hugh Singleton, dwellyng in Creede Lane, at the signe of the golden Tunn, neer vnto Ludgate. ProQuest. 
A Spiritual and most preciouse perle, teachynge all men to loue \& imbrace ye crosse as a most swete and necessarye thinge unto the soule: what comfort is to be taken thereof: where and howe bothe consolacion and aide in al maner of afflyccions is to bee sought: and agayne howe all men should behaue themselves therin, accordyng to the Word of God. London: Messrs. Longman, Hurst, Rees, Orme, and Browne, Paternoster, 1812. https://archive.org/details/ spiritualmostpre00werd.

Perl 1595

Werdmüller, O., 1511-52 (1595), Perl mewn adfid neu, perl yspiydawl, gwyrthfawrocafyn dyseu i bôb dyn garu, a chofleidio y grocameis peth hyfryd angenrheidiawl ir enaid, pagorffordd syww gael o honi, ple, ac ym ha fodd, $y$ dylid ceisiaw diddanwch, a chrymorth yni holadfyd: A thrachefn, pe wedd y dyle bawh $i$ vmddwyn $i$ hunain mewn blinder, yn ol gair auw. a escrifonnwyd yn gyntaf mewn doitich gann bregethwr dyscedig otho wermulerus, ac a droed ir saesonaeg gann D. miles coverdal, ac yvawrhon vn hwyr ir gambraeg gann. H.L Oxford: Joseph Barnes. ProQuest.

Voyage 1581

Cartigny, J. D., 1520?-78 (1581), The voyage of the wandering knight. deuised by iohn carthenie, a frenchman: And translated out of french into english, by VVilliam goodyear of south-hampton merchant. A vvorke vvorthie of reading, and dedicated to the right worshipfull sir frauncis drake, knight London, By Thomas East. ProQuest. 


\section{References}

Geoffrey of Monmouth, 2007, The History of the Kings of Britain, Latin text edited by Michael D. Reeve, translated by Neil Wright, Woodbridge: Boydell Press (Arthurian Studies 69).

Gambold, W., 1817, Welsh Grammar; or, a Short and Easy Introduction to the Welsh Tongue, Carmarthen: J. Evans.

Geinitz, L., 2019, Adjektive mit-edig- Suffix: Untersuchungen zu ihrer Funktion in zwei frühneukymrischen Übersetzungstexten anhand ibrer Äquivalente in den englischsprachigen Quelltexten, unpublished B.A. Thesis, University of Marburg.

Generalova, V., 2016, Актанты мотивирующего глагола в семантике русских отглагольных прилагательных [Actants of Derivation Verb in the Semantics of Russian Verbal Adjectives], unpublished B.A. Thesis, Saint Petersburg University. Haspelmath, M., 1994, 'Passive Participles across Languages', in: Fox, B.A. \& Hopper P.J., eds., Voice: Form and function, Amsterdam: Benjamins, 151-77.

Isaac, G. R., Kapphahn, K., Nurmio, S., Rodway, S., \& Sims-Williams, P., 2013, Rhyddiaith Gymraeg o Lawysgrifau'r $13^{\text {eg }}$ Ganrif/13 ${ }^{\text {th }}$ Century Welsh Prose Manuscripts, Aberystwyth: Aberystwyth University, DOI 10.20391/3abf4ef1-e364-4cce-859d-92bf4035b303.

Lefèvre, Y., 1954, L' Elucidarium et les lucidaires: Contribution, par l'histoire d'un texte, à l' histoire des croyances religieuses en France au moyen âge, Paris: De Boccard.

Luft, D., Thomas, P. W., \& Smith, D. M., 2013, Rhyddiaith Gymraeg 1300-1425. http:// www.rhyddiaithganoloesol.caerdydd.ac.uk.

Mittendorf, I., \& Willis, D., 2004, A Historical Corpus of the Welsh Language 15001850, http://people.ds.cam.ac.uk/dwew2/hcwl/menu.htm.

Morris-Jones, J., 1913, A Welsh Grammar, Historical and Comparative: Phonology and Accidence, Oxford: The Clarendon Press.

Morris-Jones, J., \& Rhŷs, J., 1894, The Elucidarium and Other Tracts: in Welsh from Llyvyr agkyr Llandewivrevi A.D. 1346 (Jesus college ms. 119), Oxford: The Clarendon Press.

Nurmio, S., 2019, 'Grammatical Number in Welsh: Diachrony and Typology', Transactions of the Philological Society 117 (S1), 1-272.

Oesterley, H., 1872, Gesta Romanorum, Berlin: Weidmannsche Buchhandlung. Parina, E., 2015, 'Welsh Translations from English (16 ${ }^{\text {th }}$ to $19^{\text {th }}$ century): a Digital Parallel Edition', http://www.online.uni-marburg.de/welshtranslations/.

Parina, E., \& Poppe, E., forthcoming, Translating Devotion in Medieval Wales. Studies in the Texts and Language of Llyfr Ancr Llanddewibrefi.

Phillips, T. O., 1959, 'Llywelyn Sion (1540-1615?)', Dictionary of Welsh Biography, https://biography.wales/article/s-LLYW-SIO-1540.

Poppe, E., in prep., 'The translation of Morphological Descriptions in Gruffydd Robert's Sixteenth-century Welsh Grammar'. 
Robert, G., 1939, Gramadeg Cymraeg: gan Gruffydd Robert: yn ôl yr argraffiad y dechrewyd ei gyhoeddi ym Milan yn 1567 [Welsh Grammar by Gruffydd Robert: after the edition in Milan published from 1567], Caerdydd: Gwasg Prifysgol Cymru. Rottet, K. J., \& Morris, S., 2018, Comparative Stylistics of Welsh and English: Arddulleg y Gymraeg, Cardiff: University of Wales Press.

Rowles, S., 2008, Yr Elucidarium: Iaith, Strwythur, Cynnwys ac Arwyddocâdy Cyfieithiadau Cymraeg. [Yr Elucidarium: Language, Structure, Contents and Significance of the Welsh Translations], unpublished PhD thesis, Aberystwyth University.

Russell, P., 1990, Celtic Word-Formation: The Velar Suffixes, Dublin: Dublin Institute for Advanced Studies.

Shagal, K., 2019, Participles: A Typological Study, Berlin, Boston: De Gruyter Mouton. Strachan, J., 1909, An Introduction to Early Welsh, Manchester: Manchester University Press.

Thomas, G. C. G., 1997, 'From Manuscript to Print-I. Manuscript', in: Gruffydd, R. G., ed., A Guide to Welsh Literature: c.1530-1700. Volume III, Cardiff: University of Wales Press, 241-62.

Williams, G. J., 1948, Traddodiad Llenyddol Morgannwg [Literary Tradition of Glamorgan], Caerdydd: Gwasg Prifysgol Cymru.

Williams, P., in prep., 'The Welsh Version of the Gesta Romanorum'.

Williams, W. G., 1959, 'Lewis, Hugh (1562-1634), cleric, author, poet'. Dictionary of Welsh Biography, https://biography.wales/article/s-LEWI-HUG-1562 [accessed 15.05.2020].

Zimmer, S., 2000, Studies in Welsh Word-Formation, Dublin: Dublin Institute for Advanced Studies. 
